\title{
DEVELOPMENT OF EDUCATION TOURISM IN SOUTH TANGERANG REGION (CASE STUDY: KANDANK JURANK DOANK)
}

\author{
Asep Parantika, Abu Bakar Isnaen. Sahid Institute of Tourism Jakarta. \\ asepparantika@stpsahid.ac.id
}

\begin{abstract}
Education tourism is a program where tourists visit a tourism destination with the main purpose to receive experience in education directly in the tourism object. In those places visitors could do tourism activities and also studying with fun methods. Kandank Jurank Doank is a tourism object that is located in Ciputat-South Tangerang. This tourism object which applies the concept of Education Tourism has become a choice for people of Jakarta city and around for recreation because of its location which is not far from the center of Jakarta city. This research is a descriptive with the support of qualitative data. The technique of data collecting is done through observation, questionnaire interviews, and documentation study. The informants in this research are the management parties of the tourism object Kandank Jurank Doank, in order to gain data which is actual with internal and external condition in Kandank Jurank Doank. Factor Analysis Internal and External is set by the management party of Kandank Jurank Doank through questionnaire technique, and then continued by relative weight calculation of Internal and External Factors with weighing questionnaire for Internal and External Factors. After finding the relative weight of Internal and External Factors, continuing with EFE Matrix and IFE Matrix to determine the total score of EFE and IFE which later will be used to scale the I-E Matrix, and then continued with the SWOT Matrix to determine the strategies of development for the tourism object of Kandank Jurank Doank. And the strategy that is received from the SWOT Matrix is to develop the potencies that are possessed by the company and to keep the existing tourism concept, and also to optimize the management information system in the activities of education tourism in Kandank Jurank Doank, improving service and the quality of Human Resource, in the aspect of comfort and security in order to increase the satisfaction of the consumers, designing education tourism activites that utilize the existing space and facilities, improving the cooperation with government, local people, and also the tourists themselves, and to utilize the use of internet to maximise the promotion program and the information of the tourism object of Kandank Jurank Doank, and also to form cooperations with investors in order to help the development of Kandank Jurank Doank.
\end{abstract}

Keywords: Education Toursim, Kandank Jurank, Development Strategies, SWOT

Journal of Business on Hospitality and Tourism 


\section{A. INTRODUCTION}

Indonesia as an archipelago country that is rich in natural resources and variety of cultures which are the primary assets for the development of the country. Some example of the variety of natural resources and cultures are: the variety of flora and fauna, ancient and historical heritages, and also arts and cultures, could be used as assets for the effort of development and improvement of the tourism sector. The development of tourism sector will pull other sectors into development and it will also give positive effects for the region around the tourism object, which is the improvement of the economy and the opening of new workfields for the people around the tourism object. Marpaung (2002:19) explains, that tourism development is a development process that is for the purpose of giving benefits for the tourists and also the local people. Tourism could give a better living for the local people through the economic gains from the development of tourism destination

Kandank Jurank Doank (KJD) which is located in the region of South Tangerang is an education tourism object that offers a few packages of outbound tourism that are fun and full of benefits for its visitors, there the visitors could play outgames while learning and indirectly donating for KJD nature school. According to the data of tourists number to KJD in the year of 2006-2011 shows a rising number of tourists every year, except for the year of 2012-2014 KJD where a slight decline of tourists happened.

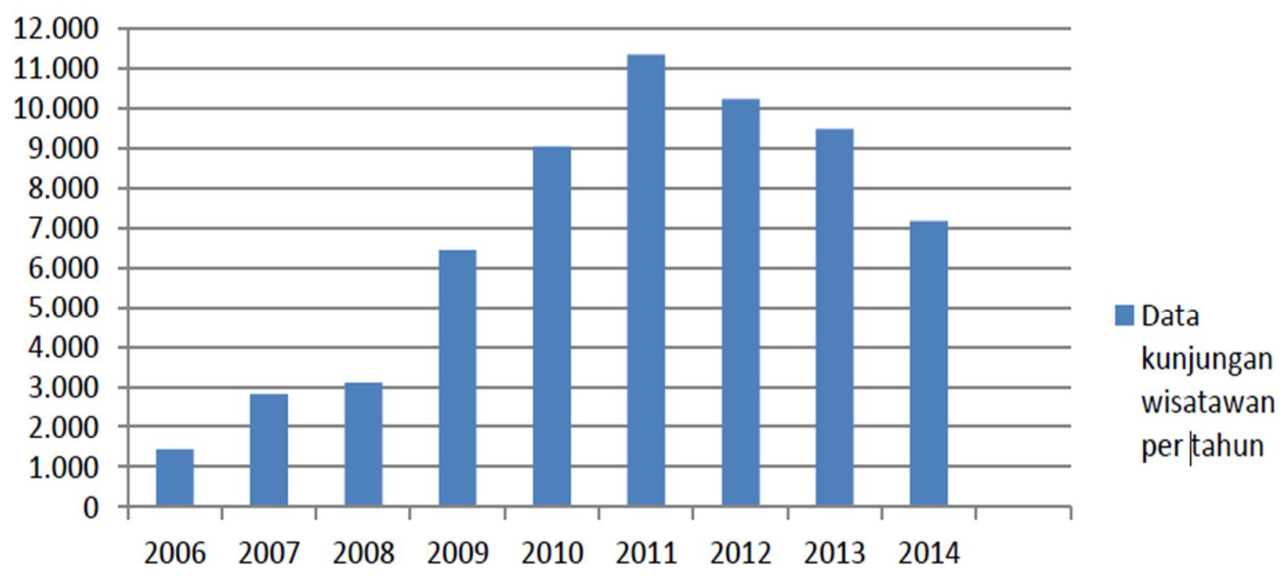

Picture 1. Graphic of KJD visitor level period 2006-2014

The appearance of some similar enterprises in Ciputat and around like in Tanah Tinggal and Dataran D'Palma Situ Gintung, demands the management of KJD to keep innovating in order to increase the number of visitor to KJD. According to the descriptions above, the writer is very interested in doing a research about the 
development of Kandank Jurank Doank as an Education Tourism Object In South Tangerang.

\section{B. RESEARCH METHOD}

The method that is used in this research is descriptive qualitative. A method that is based on the philosophy of postpositivisme, which is usually used to research the natural condition of an object (the opposite of experiment) where the researcher is the key instrument, the technique of data gathering is done with the method of triangulation (mix). The analysis of the data is inductive/qualitative, and the result of a qualitative research is more heavily focusing on meaning, rather than generalization (Sugiyono, 2012: 13). Meanwhile the goal of this descriptive research is to produce an accurate image about a group, by picturing mechanism of a process or relationship, to picture a complete image in verbal or numerical form, to present basic information or a relationship, to create a set of category and to classify the research subject, explaining a set of steps or process and also saving informations that are contradictive about the research subject. Because the research is a qualitative so the score of variables are independent, either one variable or more (independent) are done without making a comparison or making a relation between variables. In this research the writer will use only one variable which is Strategy of Education Tourism Development.

\section{Sampling Technique}

In this research, the writer use the technique of purposive sampling, which is a sampling technique with certain considerations, which are what data source that is regarded as the most knowledgeable about what is expected, so that it will make it more easy for the researcher to explore the object or the social situation that is researched (Sugiyono, 2008: 218). The important factor in a sampling of a qualitative research is the completeness of information gathering with the existing varietes, not on the number of samples. The technique is done by doing a Deep Interview and a direct observation to the location of the research, and also spreading 10 questionnaires for 10 respondents or informants which are also the management of Kandank Jurank Doank.

\section{Data Analysis Method}

Method that is analyzed by the method of qualitative that is often used in development of alternative strategy in the development of Kandank Jurank Doank tourism object. In determining an alternative strategy, strategy formulation is required, which are: in first step, using matrix analysis of External Factor Evaluation (EFE), and Internal Factor Evaluation (IFE). The second step, by using I-E (Internal-External) Matrix and Strength, Weakness, Opportunities, Threats (SWOT). 


\section{a, IFE and EFE Matrix}

External Factor Evaluation (EFE), and Internal Factor Evaluation (IFE) are a common tool to be used in formulizing a strategy. The EFE matrix could help in decision making in summarizing and evaluating of information of political, economic, social culture, demograph, environment, and technology. And also information about consumer, competition, obstacles, and entry of newcomers. Meanwhile the IFE matrix summarizes and evaluates strengths and weaknesses in various functional aspects of an enterprise which consists of management function, financial, production, operation, human resources, marketing, and management information system.

\section{b. I-E Matrix}

Internal-External (I-E) matrix is a combination of strategic factor between IFE and EFE. I-E matrix is analyzed in order to find the position of the company in the moment and to formulize a strategy which could be applied by the company. The I-E matrix could be seen as below.

Picture 2. Example of I-E Matrix Table

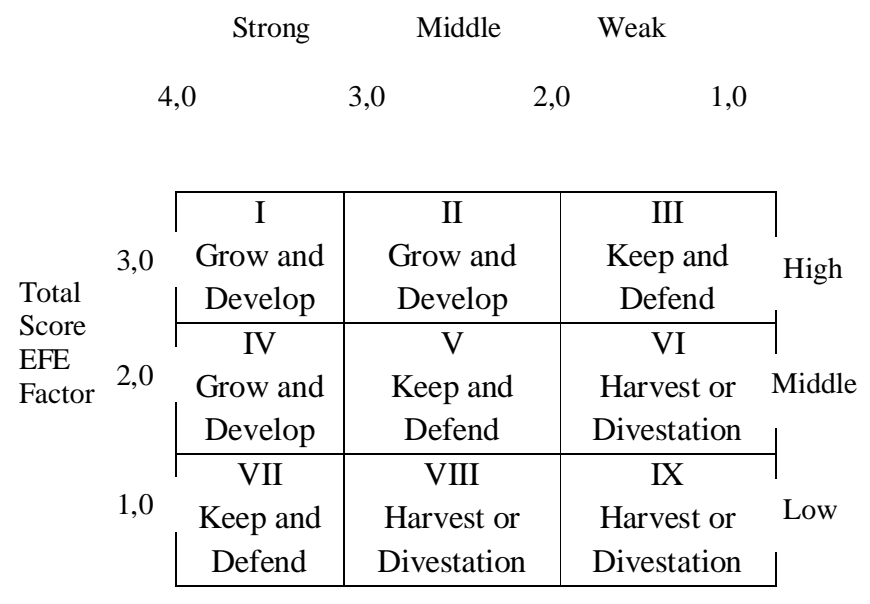

I-E Matrix could be divided into three main sections that have implication on different strategies. The three main sections are First, covering the cells I, II, and IV included in the section of grow and develop. The strategy that fits this section is intensive strategy, like market penetration, product development, and integration strategy like horizontal and vertical integration.

Second, covering the cells III, V, and VII, the best strategy that could be managed and guarded. Market penetration and product development are the two strategies that are done the most for this type of division. Third, covering the cells VI, VIII, and IX is the section of harvest and divest. 


\section{c. SWOT Matrix}

SWOT matrix is a device of matching that is important to help making a decision in developing a company and there are four type of strategy : SO strategy, WO strategy, ST strategy, and WT strategy. Datas and informations used by each strategy is received from the IFE and EFE matrix. SWOT matrix could be seen in the image below :

Table 2. Example of SWOT matrix table

\section{SWOT Matrix Table}

\begin{tabular}{|c|c|c|}
\hline Intemal Factor & STRENGTH -S & WEAKNESS - W \\
External Factor & A list of Strength & A list of Wealness \\
\hline OPPORTUNITIES - 0 & $\begin{array}{c}\text { STRATEGY - SO } \\
\text { Use the strength by } \\
\text { using opportunities }\end{array}$ & $\begin{array}{c}\text { STRATEGY - WO } \\
\text { Handle weakness by } \\
\text { using oppotunities }\end{array}$ \\
\hline THREATS - T & $\begin{array}{c}\text { STRATEGY - ST } \\
\text { A list of Threats }\end{array}$ & $\begin{array}{c}\text { STRATEGY - WT } \\
\text { Minimize weakness to } \\
\text { avoid threats }\end{array}$ \\
\hline
\end{tabular}

1. Making a list of internal strength of tourism object KJD.

2. Making a list of internal weakness of tourism object KJD.

3. Making a list of external opportunities of tourism object KJD.

4. Making a list of external threats of tourism object KJD.

5. Matching internal strength with external opportunities and recording the result in SO strategy.

6. Matching internal weakness with external opportunities and recording the result in WO strategy.

7. Matching internal strength with external threats and recording the result in ST strategy.

8. Matching internal weakness with external threats and recording the result in WT strategy.

\section{DESCRIPTION OF RESEARCH RESULT}

Based on the result of observation that is done by the writer, there is a description of environment that they faced, eather from inside environment of the company or outside environment of the company 
The management of KJD in doing their opperasional activities could use internal condition or external condition in their bussiness development.

1. Here is that description of internl condition factor of KJD :

1). Strengths

KJD has the strenghts taht could be use and development of the future in the middle of similar enterprises that are emerging . those strengths are :

- Vision and Mission of Company

- The Variation of outbound product that is offered.

- The use of information system management (Internet and computer).

- Finance recording system

- Staff's service towards visitors/guide.

- The completeness off visitors facilities and education facilities.

2). Weakness

Weakness is a barrier for development tourism industry, the Weakness could disturb maximum achievement that is targeted. Those Weaknesses of the KJD are :

- Promotion activity that is not yet optimum.

- The status of land ownership (outbound area and rice field)

- Minimum access and direction to allocation.

2. External Factors influencing the development of KJD tourism object.

1). Opportunities

- Support from local government

- Visitor number level that is rising in the holiday season

- Development of technology and information

- Economical condition which is better could raise demands of visitors towards recreation

- Life style of urban communities that wants to be back to nature

- The development of the people's mindset about education tourism

2). Threats

- Climate condition that is unpredictable

- Rise of basic needs prices

- The existence of competitors with the same concept around Kandank Jurank Doank

- Political situation that could be a big threat someday

- Takeover of the land from the party of land owners (outbound and ricefields) 


\section{DISCUSSION}

According to identification of the Internal External condition of the KJD Tourism Object, the information about Strength and Weakness could be found, and could be seen from the table below:

Table 3. KJD Internal Factors

\begin{tabular}{|c|l|c|l|}
\hline \multicolumn{3}{|c|}{ Intemal Factors } \\
\hline No. & \multicolumn{1}{|c|}{ Strength } & No. & \multicolumn{1}{|c|}{ Weakness } \\
\hline 1 & Vision and Mission & 1 & $\begin{array}{l}\text { Promotion activity that is still } \\
\text { not optimum }\end{array}$ \\
\hline 2 & Outbond product variation & 2 & $\begin{array}{l}\text { Land ownership status (Outbond } \\
\text { and nicefield area) }\end{array}$ \\
\hline 3 & $\begin{array}{l}\text { The use of Management } \\
\text { Information System(Computer } \\
\text { and Intemet) }\end{array}$ & 3 & The difficult access to the area \\
\hline 5 & $\begin{array}{l}\text { Financialrecording system } \\
\text { Staff service towards visitors } \\
\text { and guides }\end{array}$ & & \\
\hline 6 & $\begin{array}{l}\text { Completeness of visitor's } \\
\text { facilities and education facilities }\end{array}$ \\
\hline
\end{tabular}

Table 4. KJD External Factors

\begin{tabular}{|c|l|c|l|}
\hline \multicolumn{4}{|c|}{ Extemal Factors } \\
\hline No. & \multicolumn{1}{|c|}{ Opportunity } & No. & \multicolumn{1}{c|}{ Threat } \\
\hline 1 & Support of local govemments & 1 & Unpredictable climate condition \\
\hline 2 & $\begin{array}{l}\text { Level of visitor number that is } \\
\text { rising in school holidsy season }\end{array}$ & 2 & $\begin{array}{l}\text { The rise of basic nesds goods } \\
\text { price }\end{array}$ \\
\hline 3 & $\begin{array}{l}\text { Development of technology and } \\
\text { information }\end{array}$ & 3 & $\begin{array}{l}\text { The existence of competitor } \\
\text { with similar concept }\end{array}$ \\
\hline 4 & $\begin{array}{l}\text { Better economical condition } \\
\text { could raise visitor's demand } \\
\text { towards recreation }\end{array}$ & 4 & $\begin{array}{l}\text { Political situation that someday } \\
\text { could be a big threat }\end{array}$ \\
\hline 5 & $\begin{array}{l}\text { Uroan communities lifestyle } \\
\text { that wants to be back to nature }\end{array}$ & 5 & $\begin{array}{l}\text { Takeover of land ownership by } \\
\text { the party of landowner (outbond } \\
\text { area and ricefields }\end{array}$ \\
\hline 6 & $\begin{array}{l}\text { The development of the } \\
\text { people's mindset about } \\
\text { education tourism }\end{array}$ & \multicolumn{2}{l}{} \\
\cline { 1 - 4 }
\end{tabular}

\section{a. IFE and EFE Matrix}

After determining the internal strategy factors of the KJD tourism object that are becoming the strength and weakness towards the activities of its management, next is the appliance of rating and weight towards each factors. The appliance of these ratings and weights is for the purpose to arrange the Internal Factor Evaluation (IFE) Matrix and to know the internal strategic factors of KJD relating to strength and weakness that are regarded as important. Score value that is received could give a description about strategic factors that is becoming the main strength and weakness for KJD. IFE matrix could be seen on the table below. 
1). Internal Factors Evaluation (IFE)

\begin{tabular}{|c|c|c|c|}
\hline Internal Strategic Factor & Weight & Rating & Weight Score \\
\hline \multicolumn{4}{|l|}{ Strength } \\
\hline 1. Vision and Mission & 0,116 & 3,9 & 0,452 \\
\hline $\begin{array}{l}\text { 2. Variation of Outbond } \\
\text { product }\end{array}$ & 0,120 & 3,8 & 0,456 \\
\hline $\begin{array}{l}\text { 3. The use of Information } \\
\text { Management System } \\
\text { (Computer and Internet) }\end{array}$ & 0,083 & 3,5 & 0,291 \\
\hline 4. Financial Recording system & 0,090 & 3,1 & 0,279 \\
\hline $\begin{array}{l}\text { 5. Staff Service towards } \\
\text { visitors/guides }\end{array}$ & 0,130 & 4,0 & 0,494 \\
\hline $\begin{array}{l}\text { 6. Completeness of visitor's } \\
\text { and education facilities }\end{array}$ & 0,120 & 3,8 & 0,456 \\
\hline \multicolumn{4}{|l|}{ Strength } \\
\hline $\begin{array}{l}\text { 1. Promotion activities that are } \\
\text { not optimum yet }\end{array}$ & 0,094 & 1,4 & 0,132 \\
\hline $\begin{array}{l}\text { 2. Ownership status of the land } \\
\text { (Outbond area and ricefield) }\end{array}$ & 0,151 & 2,0 & 0,302 \\
\hline $\begin{array}{l}\text { 3. The difficult access to the } \\
\text { location }\end{array}$ & 0,096 & 1,4 & 0,134 \\
\hline Total & 1,000 & & 2,996 \\
\hline
\end{tabular}

Table 5. Internal Factor Evaluation (IFE) Matrix

According to the calculation of IFE matrix that is done to the KJD, the main strength is their service towards the customer/guide $(0,494)$. Meanwhile the minor strength for KJD is the financial recording system $(0,279)$. From the data obtained also could be found that the main weakness of KJD is the land ownership status (Outbound area and the ricefield) with the total score of 0.302. Meanwhile the minor weakness of the KJD is the promotion activitiy that is not yet optimum (0.132). As a whole according to the table above, it is known that the total score of the internal strategic factors of KJD is 2.996. This shows that KJD is in the condition of above average (2.50) which means that the position of KJD could still use their strengths to handle their weaknesses.

\section{2). External Factor Evaluation (EFE)}

According to the calculation of the EFE matrix that is done the KJD, it could be determined that the opportunity that is very impactful to the development of $\mathrm{KJDis}$ the visitor number level that is rising in the holiday season (0.282). 
Tabel 6. External Factor Evaluation (EFE) Matrix

\begin{tabular}{|c|c|c|c|}
\hline External Strategic Factor & Weight & Rating & $\begin{array}{l}\text { Weight } \\
\text { Score }\end{array}$ \\
\hline \multicolumn{4}{|l|}{ Opportunity } \\
\hline 1. Support of local government & 0,102 & 2,7 & 0,275 \\
\hline \multirow{2}{*}{$\begin{array}{l}\text { 2. Level of vis itor number that } \\
\text { increase in school holiday sea }\end{array}$} & \multirow[t]{2}{*}{0,083} & \multirow[t]{2}{*}{3,4} & \multirow[t]{2}{*}{0,282} \\
\hline & & & \\
\hline $\begin{array}{l}\text { 3. The development of technologyy } \\
\text { and information }\end{array}$ & 0,079 & 2,4 & 0,190 \\
\hline 4. Economic condition that is better & 0,088 & 2,6 & 0,229 \\
\hline $\begin{array}{l}\text { could raise the vis itor's demand } \\
\text { for recreation }\end{array}$ & & & \\
\hline $\begin{array}{l}\text { 5. Life style of urban communities } \\
\text { that wants to be back to nature }\end{array}$ & 0,084 & 3,1 & 0,260 \\
\hline \multirow{2}{*}{$\begin{array}{l}\text { 6. Development of the people's } \\
\text { mindset about education tourism }\end{array}$} & \multirow[t]{2}{*}{0,088} & \multirow[t]{2}{*}{2,4} & \multirow[t]{2}{*}{0,211} \\
\hline & & & \\
\hline \multicolumn{4}{|l|}{ Threat } \\
\hline 1. Unpredictable climate condition & 0,091 & 2,3 & 0,209 \\
\hline 2. Rise of basic needs price & 0,095 & 2,3 & 0,219 \\
\hline $\begin{array}{l}\text { 3. Existence of competition with } \\
\text { similar concept nearby }\end{array}$ & 0,081 & 2,9 & 0,235 \\
\hline $\begin{array}{l}\text { 4. Political situation that someday } \\
\text { could be a big threat }\end{array}$ & 0,095 & 2,1 & 0,200 \\
\hline $\begin{array}{l}\text { 5. Takeover of land ownership by } \\
\text { the party of landowner (outbond } \\
\text { and rice field area) }\end{array}$ & 0,113 & 3,9 & 0,441 \\
\hline Total & 1,000 & & 2,751 \\
\hline
\end{tabular}

Meanwhile the opportunity that has the smallest impact is the development of technology and information(0.190). From the data obtained, it can be determined that the threat that could affect the KJD is the ownership takeover by the landowner party (Outbound area and ricefield) with the total score of 0.441 . Meanwhile the smallest threat for KJD is the political situation that someday could be a big threat $(0.200)$. As a whole according to the Table 11 above, it could be known that the total score of external strategic factors of KJD is only 2.751. This shows that KJD is in the condition of above average (2.50) which means, the position of KJD could utilize the opportunities that they have according to the score of respondents to reduce threats that they face.

a. Internal External (I-E) Matrix

After the score of IFE matrix that gives a description about strengths and weaknesses is obtained and the EFE matrix that shows the condition of opportunities and threats that are faced by KJD, next the company could do the step of matching IFE matrix and EFE matrix. According to the score received from IFE matrix and EFE matrix, it could be determined that the position of KJD on the Internal-External (IE) matrix. The IE matrix could be seen in the table below: 
b. Matrix Internal External (I-E)

when th score of matrix IFE which is giving the description of the strength and weakness and matrix EFE which is giving the description of the condition of oportunity and threat faced by KJD is known, then company is completely able to do the guiding step between matrix IFE nd matrix EFE, it will show the position of KJD in Matrix internal-external (IE). Matrix I-E can be seen in the picture below :

Picture 3. Matrix I-E

total weight score IFE

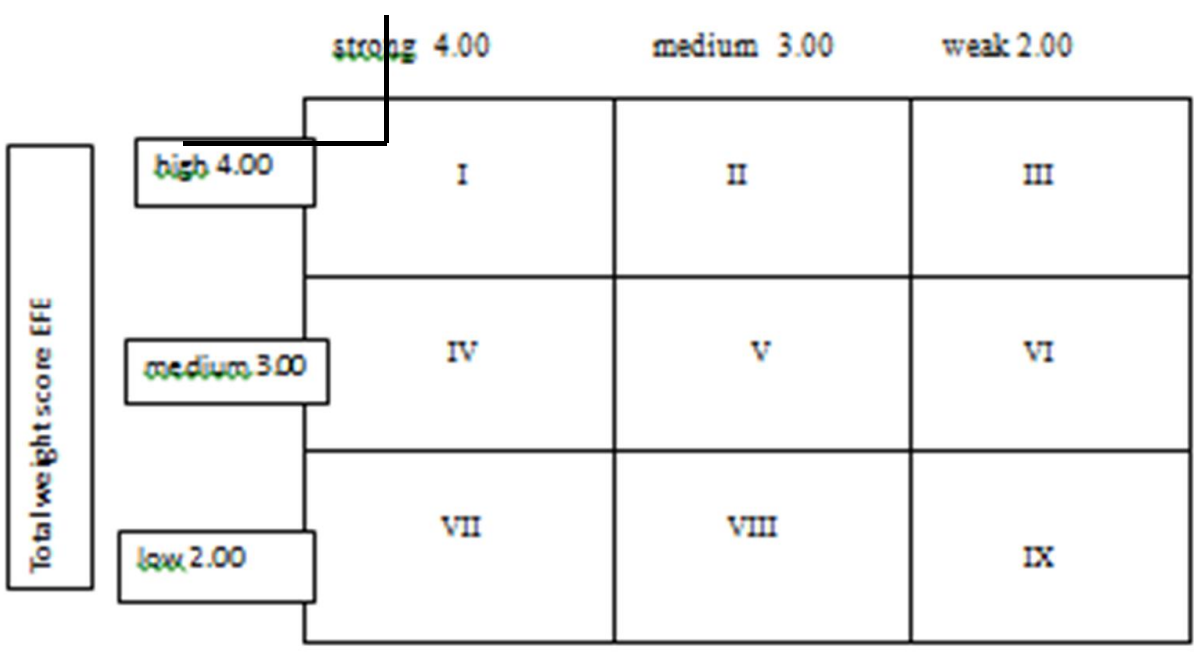

Matriks I-E used for finding out the position of the company right now based on the total weight score IFE and EFE. Amount of total weight score is 2.996 while the total weight score EFE is 2.751. based on total weight score from the matriks IFE dan matriks EFE. Place KJD in quadran V, that means the strategy that can held for sel V is keep and maintain. Strategy that usually used in this position is doing market penetration and product developing. There are some methods to do market penetration, such as optimalyze the application of print media and electronic media to promote KJD that will increase the demand of people to visit KJD. And also to listen every tourist's complain in order to make them feel respected and feel comfort to do their activity in KJD in order to make them feel satisfied.

c. Matrix SWOT

Matriks SWOT is the important matching tool to help the decision taker in developing a company, there are 4 type of strategy : strategy SO, strategy WO, strategy ST and strategy WT. Data and information used by each strategy take from matrix IFE and EFE. Result of matrix SWOT analysis can be seen in the picture: strategy WO, strategy ST, strategy WT. Data and information used by each strategy take from matrix IFE and EFE. Result of matrix SWOT analysis can be seen in the picture below: 


\begin{tabular}{|c|c|c|}
\hline IFE & $\begin{array}{l}\text { Strength (S) } \\
\text { Vision and mission of the company. } \\
\text { Variety of outbound product offer. } \\
\text { Application of information and } \\
\text { management system. } \\
\text { Finance recording system. } \\
\text { Services of the employees to the visitor } \\
\text { and colleague. } \\
\text { Facilities completeness for visitor and } \\
\text { facilities for education. }\end{array}$ & $\begin{array}{l}\text { Weakness (W) } \\
\text { Presentation activity that still minimum. } \\
\text { Area owning (outbound area and rice } \\
\text { field) } \\
\text { Access to the location that still unclear. }\end{array}$ \\
\hline $\mathrm{EFE}$ & $\begin{array}{l}\text { Oportunity ( } \mathbf{O}) \\
\text { Support from the govement. } \\
\text { Level of visitor that will increase when } \\
\text { the school holiday is come. } \\
\text { The development of technology and } \\
\text { information. } \\
\text { Better economic condition will increase } \\
\text { the visitor demand on recreation. } \\
\text { People's lifestyle that want to be bac to } \\
\text { nature }\end{array}$ & $\begin{array}{l}\text { Threat }(\mathrm{T}) \\
\text { Unpredictable climate condition. } \\
\text { The increase of basic price of principle } \\
\text { commodity. } \\
\text { The existence of the same kind bussiness } \\
\text { around KJD } \\
\text { Politic situation that will be a threat one } \\
\text { day. }\end{array}$ \\
\hline
\end{tabular}

\begin{tabular}{|c|c|}
\hline $\begin{array}{l}\text { Strategy S.O } \\
\text { Developing potentials owned by the company } \\
\text { and still maintain the tourism concept. } \\
\text { (S1,S2,S3,S5,S6,01,040,05,O6) } \\
\text { Optimize management information system } \\
\text { within tourism education activity in KJD } \\
(\mathrm{S} 3, \mathrm{~S} 4, \mathrm{O} 2, \mathrm{O} 3)\end{array}$ & $\begin{array}{l}\text { Strategy W.O } \\
\text { Increase good cooperation between govemment, } \\
\text { local people, and the tourists. } \\
\text { (W2,W3,O1,O2,O4,O5,O6) } \\
\text { Utilize the application of intemet to maximize } \\
\text { the information and promotion of tourism object } \\
\text { (KJD) activity. } \\
\text { (W1,W3,O3) }\end{array}$ \\
\hline $\begin{array}{l}\text { Strategy S.T } \\
\text { Increasing service and quality of human } \\
\text { resources in safety and comfort side in order to } \\
\text { reach the level of consumer's satisfaction. } \\
(\mathrm{S} 1, \mathrm{~S} 2, \mathrm{~S} 3, \mathrm{~S} 5, \mathrm{~S} 6, \mathrm{~T} 1, \mathrm{~T} 3, \mathrm{~T} 4) \\
\\
\text { Designing altemative education tourism activity } \\
\text { by using the available facilities and area. } \\
(\mathrm{S} 4, \mathrm{~S} 6, \mathrm{~T} 3)\end{array}$ & $\begin{array}{l}\text { Strategy W.T } \\
\text { Make a good corporation with the investors to } \\
\text { help the development of KJD. } \\
\text { (W1,W2,W3,T1,T2,T3,T4,T5) }\end{array}$ \\
\hline
\end{tabular}

\section{a. Strategy S-O}

Strategy S-O is the strategy that using strength by using oportunites that exist. This strategy made for optimalyzing the strength of KJD by responding the oportunities that exist.alternative strategy S-O. Such as :

1) Developing potencies that company has and still maintaining tourism concept that exist (S1, S2, S5, S6, O1, O4, O5. O6). KJD has potential that developable to become an interesting education tourism object, because KJD has advantages that cant be found in the other tourism places. The owner of KJD is a famous indonesian artist, thats why some tv media frequently come to this place to report tourist activity or social activity held in KJD. Besides, KJD has unique tourism concept that is "learn, play and give", so the visitors will play while getting additional lessons that 
formal education cant give. Besides, indirectly the visitors also did charity to the local people around KJD.

2) Optimalyzing management information system within operational activity in KJD (S3, S4, O2, O3,). Nowadays the development of information technology is growing fast, and in it's development is aplicable to many field. In administration system KJD has applied it, but has not running optimal yet. KJD has to use the opportunity exist to use the development of information technology.

\section{b. Strategy S-T}

1) Increase the quality of service and human resources from safety and comfort side of visitors. In order to reach the level of consumer's satisfaction (S1, S2, S3, S5, S6, T1, T3, T4). Level of consumer's satisfaction is the most important thing to keep a good relation with the consumers. Because good relation between a company and it's consumer will give positive feedback for the company. Besides the interest of consumer to come back and use the company's service again, indirectly the consumers will be important promotional tools for the company. Therefore, KJD has to keep increasing the quality of service and quality of human resources they have. Because good quality service will increase the level of visitor's satisfaction of KJD.

2) Designing alternative education tourism activity by using the available facilities and area. (S4, S6, T5). Take over outbound area and rice field by the area owner is the strongest threat for KJD, because the area owner can take back outbound area and rice field that used by KJD for education tourism activity. Therefore KJD have to design an alternative education tourism activity to prevent that problem, such as removing outbound area to the available area, or making an attraction such as dance performance, music, paint art, and theatre that will take entrance fee from the audiences.

\section{c. Strategy W-O}

1) Make a good cooperation with government, local people and the visitors (W2, W3, O1, O2, O4, O5, O6). Keep a good cooperation with government is one of the important things for the tourism object. By getting support from the government, KJD will get easier way in governmentally affairs. For example in licensing, or in solving cases such as land acquisition (outbound area and rice field) which are the status still owned by the local people. Keep a good cooperation with local people also important, besides it will causing safety and comfort condition for the tourist, good cooperation also will help the economic condition of local people, because new tourism object will bring new job vacancies. 
1) Optimalyze application of internet media to maximize promotion and tourism object information KJD (W1, W3, O3). Internet media is one of the complete information sources for human. Nowadays mostly people use internet as the media to get informations and communicating each other. every people use internet no matter how old they are, even they're old people or teenager etc. Knowing that opportunity, KJD should use internet as a media to promoting KJD and giving tourism object information of KJD. There are many ways to do promotion, such as making a website system to promoting KJD and giving complete information about KJD. So, the tourists will be more interested to visit KJD, and make them easier when looking for the information such as tour package information, tourist services, and the access to reach the location.

d. Strategy W-T

1) Make a good corporation with the investors to help the development of KJD.

The presence of investor in developing tourism object is important. In this case, investor could help KJD in solving problem about area owning, the presence of investor will help KJD winning the case because the problem faced by KJD is the selling price of the area which is high.

\section{E. CONCLUSION}

1. Based on data result of analysis, identification strategic factor that become the main strength of KJD is employees service to the visitor / coleague. With total weight score 0.494 .

2. Meanwhile the other factor identificated as the strength of KJD is the vision and mission of the company, variety of outbount product offer, management information system application (computer and internet), financial recording system, visitors facilities and education facilities.

3. Then internal strategic factor that become the main weakness in KJD is, area ownership status, with weight score 0.302 .

4. While the other factor identificated as the weakness of KJD is, promotion activity that still limited and the access to the location that still unclear.

identification of external factor that become the main oportunity in KJD is the level number of visitor that increased when the holiday season comes.

5. identification of external factor that become the main oportunity in KJD is the level number of visitor that increased when the holiday season comes. With weight score 0.282 .

6. the other factor identificated as the oportunity in KJD is the support from the local government, development of information and technology, better economic condition will increase the demand of people to do recreation, 
people's lifestyle that want to back nature, improvement of social mindset about education tourism.

7. While the external strategic factor that become main threat for KJD is area ownership with total weight score 0,441 .

8. Meanwhile the other factor identificated as the threat for KJD is unpredictable climate condition, the price of basic needs that increase, competitor around KJD, politic situation that will threat one day.

9. Alternative strategy in developing KJD by using matrix SWOT. External strategic factor identificated as main oportunity in KJD is the amount of visitors that increase.

10. By using matriks SWOT.

\begin{tabular}{|c|c|}
\hline $\begin{array}{c}\text { Strategy } \\
\text { S-O }\end{array}$ & $\begin{array}{l}\text { - Developing potencies that company has and still } \\
\text { maintaining tourism concept exist. } \\
\text { - Optimalyze management information system in education } \\
\text { tourism activity in KJD. }\end{array}$ \\
\hline $\begin{array}{l}\text { Strategy } \\
\text { S-T }\end{array}$ & $\begin{array}{l}\text { - Increasing service and quality of human resources from } \\
\text { safety and comfort side in order to reach the level of } \\
\text { consumer satisfaction. } \\
\text { - Designing alternative education tourism activity by using } \\
\text { available facilities and area. }\end{array}$ \\
\hline $\begin{array}{l}\text { Strategy } \\
\text { W-O }\end{array}$ & $\begin{array}{l}\text { - Increasing good cooperation between government, local } \\
\text { people and also the tourists. } \\
\text { - Using internet media to maximize promotion activity and } \\
\text { information of KJD. }\end{array}$ \\
\hline $\begin{array}{l}\text { Strategy } \\
\text { W-T }\end{array}$ & $\begin{array}{l}\text { - Make a good cooperation with investor to help the } \\
\text { development of KJD. }\end{array}$ \\
\hline
\end{tabular}

\section{F. ADVICE}

Based on research did by the writter, we can conclude some advices that raisable to the KJD management, such as :

1. Keep the facilities and basic facilities tourism object KJD clean, add or clarifying information board or access signs to the location of KJD.

2. Buying outbound area and rice field step by step in order to make the development of KJD running well.

3. Preparing other alternative education tourism attraction by using KJD nature school's classroom, such as music classroom, dance classroom, percussion, etc, to be presented to the KJD's tourists, just like education tourist attraction in Saung angklung mang udjo, bandung.

4. Add more tourist attraction that beneficial for the tourist and for the management of KJD, that is "Garbage Recycle" program, where the tourists comes has to bring useless goods but still usable, for charity 
program, those goods will be given to the people needed, similar with KJD's tourism concept, that is playing while learning and giving.

\section{BIBLIOGRAPHY}

Basrowi \& Suwandi. (2008). Memahami Penelitian Kualitatif. Jakarta, Rineka Cipta

David, Fred R. (2006). Manajemen Strategy Konsep. Buku 1, Edisi Ke 10. Versi Bahasa Indonesia. Jakarta, Salemba Empat

David Fred R. (2011). Manajemen Strategy Konsep edisi ke 12 Bahasa Indonesia, Jakarta, Salemba Empat

Effein, Sujoko S. (2004). Metode Penelitian Untuk Akuntansi. Jawa Timur, Bayu Media Publishing

Ismayanti. (2010). Pengantar Pariwisata. Jakarta Grasindo Gramedia Widiasarana Indonesia

Jorgiyanto.. (2005). Sistem Informasi Stratejik Untuk Keunggulan Kompetitif . Yogyakarta, Andi

Munir . (2010). Educational Tourism: Pariwisata Pendidikan.

http://munir.staf.upi.edu/2010/10/11/educational-tourism-pariwisata-pendidikan/ diakses pada 20 Juli 2015 pukul: 09.00 WIB

Nilasari, Senja. (2010) Manajeman Strategii iiu gampang untuk pemula dan orang awam. Jakarta, Gramedia Pustaka Utama

Sedarmayanti. (2014). Membangun dan Mengembangkan Kebudayaan dan Industri Pariwisata. Jakarta, Refika Aditama

Sekaran, Uma. (2006). Metodologi Penelitian Untuk Bisnis, Buku 1 Edisi 4. Jakarta, Salemba Empat

Solihin, Ismail. (2002). Manajemen stratejik. Jakarta, Erlangga

Sugiyono, (2008). Metode Penelitian kuantitatif, kualitatif dan R\&D. Bandung, Alfabet.

Sugiyono, (2011). Metode Penelitian Pendidikan. Bandung, Alfabeta 
Sugiyono, (2012). Metode Penelitian kuantitatif, kualitatif dan $R \& D$. Bandung, Alfabeta

Wardiyanta, (2006). Metode Penelitian pariwisata. Yogyakarta, Andi

Wardiyanto, (2011). Perencanaan Pengembangan Pariwisata, Bandung, Lubuk Agung

Yoeti, Oka A. (1996). Pengantar Ilmu Pariwisata. Bandung, Angkasa

Yoeti, Oka A. (1985). Pengantar Ilmu Pariwisata. Bandung, Angkasa

Yoeti, Oka A. (2010). Dasar-dasar Pengertian Hospitality dan Pariwisata. Bandung, Angkasa

http://studipariwisata.com/referensi/definisi-pembangunan- 